\title{
Spending time, spending money: passenger segmentation in an
}

\section{international airport}

\author{
by \\ Paul Freathy* \\ Professor of Retail Management \\ and \\ Frank O'Connell \\ President - European Travel Retail Council \\ Director - European Retail Affairs
}

*Contact author

Institute for Retail Studies

University of Stirling

Dublin Airport Authority

Stirling

Dublin

FK9 4LA

Eire

Tel: +44 1786467410

Tel: +35317044111

Fax +44 1786465290

Fax: +3531 7044647

e-mail: j.p.freathy@stirling.ac.uk

e-mail: fxoconnell@gmail.com 


\section{Authors Biography}

Paul Freathy is Professor of Retail Management at the University of Stirling and Director of the Institute for Retail Studies.

Frank O'Connell is Director European Retail Affairs for Dublin Airport Authority. He is a member of the Supervisory Board of Flughafen Düsseldorf GmbH and President of the Paris based European Travel Retail Council (ETRC). Frank O'Connell also represents Europe on the Duty Free World Council. 


\title{
Spending time, spending money: passenger segmentation in an international airport
}

\author{
Abstract \\ Changes within the air transport sector have required many European airports to either \\ develop or expand their commercial activities. Strategies have included the expansion of \\ retail space, a broadening of the tenant and merchandise mix and the development of a \\ passenger segmentation strategy. This paper explores the efficacy of this approach by \\ identifying the behaviour of different passenger segments while in an international airport. \\ Using a framework of strategic market segmentation, it identifies how travellers allocate their \\ time having entered 'airside' and details any purchases made. Using observational research \\ and a face to face quantitative survey, 301 passengers were tracked and interviewed. \\ Through a broad based, a priori form of segmentation, significant differences in shopping \\ behaviour are identified. Such findings assist with the development of the airport's \\ commercial strategy and allow a number of observations to be made about the value of \\ market segmentation from both a theoretical and managerial perspective.
}

\section{Keywords}

Retail

Airports

Commercial Strategy

Consumer Behaviour

Market Segmentation 


\section{Spending time, spending money: passenger segmentation in an international airport}

\section{Introduction}

Over the last decade the air transport sector has been required to respond to a series of commercial pressures that has threatened to undermine the future viability of a number of European airports. In particular, declining aeronautical revenues ${ }^{\mathrm{i}}$ and the abolition of tax and duty free sales on intra EU flights has significantly limited the revenue generating ability of many airport authorities. These imperatives have demanded a strategic response and led to alternative forms of commercialisation. In particular there has been a significant increase in the space dedicated to retailing, a broadening of both the tenant mix and range of merchandise sold and attempts by different airport authorities to develop passenger segmentation strategies. Partly as a consequence of these developments, the airport environment has also become the subject of considerable academic attention (CastilloManzano, 2010; Graham, 2008; Geuens et al. 2004).

While a number of these previous studies provide useful starting points, it will be argued in this paper that the actual behaviour of travelling passengers continues to remain an under researched area. How individuals actually allocate their time prior to departure and whether there are significant differences in behaviour across alternate passenger categories is still largely undocumented. Moreover there has been little discussion on how such research can be used to inform an airport's overall commercial strategy. As Dibb and Simkin (2009) note, while there have been numerous market segmentation studies, few have considered the practical issues involved in implementation. The aims of this paper are therefore twofold. First, through empirical research it investigates whether identifiable forms of behaviour are 
displayed across different passenger segments. Secondly, using the results from the research, the paper identifies the managerial benefits that can be derived from a market segmentation strategy and details some of the practical and theoretical issues that need to be considered when adopting this approach.

In order to achieve these outcomes the paper is divided as follows. First a discussion of market segmentation theory is provided. Many airports continue to divide passengers based upon a number of key identifiable attributes and this section provides a conceptual basis for understanding this approach. This is followed by a contextual section that describes briefly the airport retail environment. After the methodology is described the research findings are presented. This section details the total time respondents spent in the commercial area and the activities they undertook. The shopping patterns of different consumer segments are then examined before the motivations for purchasing are considered. Finally the reasons for not purchasing at the airport are outlined. After the empirical results are presented, the broader implications of the research are considered and a series of conclusions are drawn.

\section{Segmentation Theory}

Customer segmentation as a means of defining business priorities, reinforcing a market position and targeting resources has been a well documented approach within the academic literature (Dibb and Simkin, 1991; Moschis et al., 1997; Marcus, 1998; Paço and Raposo, 2009; Segal and Giacobbe, 1994; Sinha and Uniyal, 2005). Numerous studies have attempted to illustrate how individuals can be grouped under broad homogenous categories that display similar behavioural traits and purchasing preferences. Research has demonstrated the applicability of segmentation to sectors such as banking (Alfansi and Sargeant 2000), tourism 
and travel (Gonzalez and Bello 2002; Magson and Dipple 2004), education (Cheung et al, 2010) and the marketing of location (Leisen 2001; Ruiz et al 2004). The retail sector has also been the subject of numerous segmentation studies that have focused upon specific markets (Kımıloğlu et al 2010; Moschis et al 2004); customer loyalty (Cuthbertson and Laine 2004; Ziliani and Bellini 2004); e-commerce (Rafiq and Fulford, 2005; Tractinsky and Lowengart 2003) and retail brands (Baltas 2003; Orth et al 2004; Trinh et al 2009). Indeed Hassan and Craft (2005) argue that as a concept, segmentation occupies a pivotal role in modern marketing management.

At its simplest, customer segmentation allows an organisation to identify and evaluate the importance of key consumer groups, which in turn allows products and resources to be targeted more effectively (Dibb, 1998; Hollywood et al., 2007; Wind, 1978). The value of this approach lies in its ability to anticipate future behaviour (Riquier et al., 1997), detect, evaluate and select previously untargeted groups (Sarabia, 1996; Sudbury and Simcock, 2009) and act as a precursor to the development of a competitive strategy (Cahill, 1997; Dibb and Wensley, 2002; Quinn et al., 2007). The outcomes that stem from a successful segmentation strategy are varied and include a reduction in competitive rivalry, pricing stability, protection against substitution and an opportunity to build differentiation.

The credibility attached to a market segmentation strategy is predicated upon two key assumptions, first, that consumers can be grouped into segments that display homogenous preferences relative to other segments. Secondly, the return on investment is likely to be greater if companies match their products and marketing mix to particular segments (Green and Kreiger, 1991). Due to the increasing variety of consumer products available on the market, variations in demographic characteristics and the growing number of advertising 
media, many organisations have accepted such assumptions and used segmentation as a method of categorising consumers into discrete and manageable classifications (Foedermayr and Diamantopoulos, 2008).

There remain two major types of segmentation. First, segmentation based upon the identification of broad based, easily identifiable variables that are classed at the macro level. The objective of using this approach is to disaggregate a large market into a series of sub groups (Hassan and Craft, 2005). These may be defined before the study is undertaken ( $a$ priori) or clustered on the basis of individual responses (post hoc) (Mäenpää, 2006).

While categories such as age, gender, geographic location and account size have been widely used to formulate segmentation strategies, the limitations of using such criteria has been noted (Chetthamrongchai and Davies, 2000; Dolnicar, 2004; Harrison, 1995; Quinn et al., 2007). A second approach to segmentation therefore is to aggregate individuals into groups based on managerially relevant 'micro-segments' (Rao and Wang 1995). The objective here is to cluster individual customers into homogenous groups based on their responses to attitudinal or behavioural data (Barry and Weinstein 2009; Chiang and Dholakia, 2003; Woo, 1998). Until the 1970s this form of aggregation remained limited to product-specific systems, however the development of cluster analysis and the VALS demographic / attitudinal questionnaire represented a catalyst for the development of behavioural segmentation studies. Since that time there have been a plethora of single use segmentation schemes (Cahill 1997) using a variety of analytical techniques such as conjoint analysis and discrete choice modelling (Riquier et al 1997). The use of multi dimensional models has attempted to move away from the a priori method of segmentation and incorporate a more behavioural approach. For example categorical systems such as the Luscher Color Test and 
the Myers-Briggs Type Indicator have allowed consumers to be placed into anything from 4 108 different classifications (Bickert 1997).

A review of the literature reveals how these psychographic models have been applied. There are varied attempts to segment consumers by life-stage (Sudbury and Simcock, 2009), by patronage activity (Larrew, 1998), by birth order (Claston, 1995; Reisenwitz and Iyer, 2007), by the level of acculturation (Palumbo and Teich, 2004) as well as by ethnic origin (Kinra, 1997; Souiden, 2002) and sector (Ansell et al., 2007).

While acknowledging the alternative approaches to segmentation, Kotler (1999) maintains that to be successful a segment has to meet four criteria. First it has to be measurable. That is, the size and the purchasing power of each segment needs to be quantifiable. Secondly, the segment must be accessible and therefore marketable in a cost-effective manner. Thirdly the segment must be substantial enough in terms of profit or revenue to merit the allocation of marketing resources. Finally the segment must be actionable. This refers to the capability of the company to effectively target its chosen segment within its own budgetary and resource constraints.

Despite its popularity a number of commentators have noted that the application of market segmentation is rarely problem free. In particular a disjuncture is noted between its theoretical development and its practical application with many failures in implementation being attributed to the gap between academic research and managerial reality. Dolincar and Lazarevski (2009) for example identified that managers had a limited understanding of the procedures underlying market segmentation and as a consequence had difficulty interpreting results. Other such as Sausen et al (2005) note the limitations of normative models that 
reduce segmentation to a process for classifying consumer groups many of which may be intuitively rather than rationally derived (Quinn 2009). This however is not to deny the wider contribution that strategic market segmentation can make in achieving an organisation's corporate goals. If integrated into the planning process it can be seen as more than a marketing tool and assist an organisation in realising its business strategy (see also Dibb and Simkin 2009; Dibb and Simkin 2010).

While other commentators have also detailed the limitations of segmentation theory (Alfansi and Sargeant, 2000; Bonoma and Shapiro, 1984; Dibb, 1998; Firat and Schultz, 1997; Hoek et al., 1996; Quinn et al., 2007; Wensley, 1995; Wright, 1996), it remains a widely adopted practice in the airport sector and as Saunders (1995) noted, as a theoretical construct and practical application, it continues to remain valid.

\section{Commercial activities within the airport sector}

Over the past three decades the airport sector has experienced significant structural and compositional change. The way in which many airports are funded, controlled and governed has altered radically (Vasigh et al., 2009; Doganis, 2009). Traditionally airports have been administered and controlled either by central or local government or a state appointed body. While it remains accurate to suggest that many airports throughout the world still have some form of public sector ownership, the funding regimes under which they operate varies considerably (Graham, 2008; Humphreys and Francis, 2002).

One feature of this diverse pattern of airport ownership has been a greater participation from private sector interests and different forms of operation (Freathy and O'Connell, 1999; Kim 
and Shin, 2001). The movement towards privatisation has been prompted primarily by the state's desire to avoid the financial burdens associated with subsidising airport capital investment. Airports have traditionally had to compete with other areas of public expenditure such as education, health and defence. The increasing cost associated with operating an airport has prompted the view that airports were in an intensely competitive market and needed to be run on commercial rather than state principles (Freathy and O'Connell, 1998).

Many airports have also seen the income they derive from aeronautical activities decline as a result of intense competition within the airline industry. The charges levied on airlines by airports for using their facilities have remained relatively static since the late nineteen eighties (ACI, 2007). As ACI (2007) note, in 1990 approximately 30\% of airport revenues were derived from non aeronautical sources. By 2007 this figure had risen to between $50 \%$ and $60 \%$. This has partly been in response to government policies aimed at encouraging inbound tourism and partly due to the competitive nature of the airline industry operating on limited margins and keeping fares low (Doganis, 2009).

The entry of low fare airlines into the market has not only served to lower ticket prices, but has encouraged new patterns of consumer demand and loyalty (Malighetti et al., 2009; Pitt, 2001; Pitt and Brown, 2001; Forgas et al., 2010). Carriers such as EasyJet and Ryanair have encouraged new groups of persons to use air transport who have in turn displayed different forms of purchasing behaviour (Garcia and Royo-Vela, 2010; Kangis and O'Reilly, 2003; Pitt and Brown, 2001).

Although over a decade ago, arguably one of the biggest influences upon passenger purchasing behaviour within Europe was the legislative provisions relating to fiscal 
harmonisation across EU member states. In particular, the decision in 1999 to remove a passenger's right to purchase duty and tax free products when travelling within the EU had a significant impact upon the revenue generating capabilities of many European airports. IntraEU sales of tax and duty free were of fundamental importance for many airports as the revenues it generated could be used for infrastructure projects such as new terminal construction and runway redevelopment. The enlargement of the EU in 2004 and 2007 reduced further the number of passengers entitled to purchase tax and duty free goods on intra European flights.

\section{The Commercial Response}

The factors identified above highlight the dynamic and constantly evolving nature of the air transport industry. The responses to such challenges are many and varied and extend beyond the commercial strategies described in this paper. Nevertheless, political and consumer change, increased competition and a reconfiguration of the airline industry have prompted a series of strategic measures designed to ensure the future viability of many European airports.

One strategic response has been to increase the amount of space now dedicated to specialist shopping facilities. For example, Liverpool's John Lennon airport announced in 2009 that it was expanding its commercial area from $55,000 \mathrm{sq} \mathrm{ft}$ to $80,000 \mathrm{sq} \mathrm{ft}$, while the space specifically dedicated to retail would increase by over $45 \%$. After completion it is estimated that commercial activities will account for $22 \%$ of the total terminal area (DFNI, 2010). In many of the larger airports this physical expansion has been accompanied by a marked increase in the number and mix of retail operators. In the UK, BAA has increased its retail floor space 
(including catering) from 400,000 square feet in 1991 to over $1,070,000$ square feet in 2010 (BAA, 2010). When Heathrow Terminal 5 opened in 2008, it included a 215,000 sq foot commercial area with 144 different stores and restaurants including major brands such as Tiffany's, Cartier, Gucci and Harrods. Moreover the Terminal 5 development increased total retail floor space in Heathrow by approximately 50\% (BAA 2007). Controlling and managing a diverse tenant mix is not new, Ruiz et al. (2004) for example note how similar techniques have been used to assist in the positioning and marketing of shopping malls. In addition to improved customer service and better communications, this strategy provides a more tightly focused merchandise range, eliminates inappropriate product groups and allows the better utilisation of in-store space.

On the demand side, it has been argued that when in an airport consumers display patterns of behaviour that do not mirror traditional shopping typologies (Dholakia, 1999; Omar and Kent, 2001). While some commentators view airports as displaying a sense of 'timelessness and placelessness' (Rowley and Slack, 1999) others maintain that time pressured shoppers will make fewer purchases, (Chetthamrongchai and Davies, 2000). This latter finding may have significant implications for an airport authority as the excitement, stress or unfamiliarity of an airport environment could directly impact upon shopping behaviour.

Airport authorities have recognised the importance of understanding the behaviour of passengers and segmentation strategies have gone beyond the simple delineation of traveller / non-traveller (Geuens et al., 2004; Newman and Lloyd Jones, 1999). For example, Freathy and O'Connell (1998) identified how airports segmented their passengers on their purpose of travel, while non-passengers were segmented on their purpose of visit. The customs and security requirement to record passenger details assist in this process and allow airports to compile a detailed customer database. The outcome has been a series of broad, a priori sub- 
segments that include; Status (Domestic v International v Transit); Duration of Travel; Purpose of Travel (Business v Pleasure); Destination (Intra EU v Non-Intra EU); Airline used (Scheduled v Charter v Low cost carrier). In addition, non travelling categories may include airport staff, taxi drivers airline crews, MGWW (Meeters, Greeters, Weepers and Wailers) and local residents.

These homogenous, identifiable segments have allowed the retailer to focus resources and target more accurately the specific needs of the consumer (Freathy and O'Connell, 1998). For example, business travellers have higher levels of disposable income and have identifiable spending patterns. Furthermore business passengers are considered to have only a limited time to shop in the country in which they are visiting. Airports may therefore represent one of the primary opportunities for them to purchase products. However, as a segment, business travellers represent a challenge for the commercial operator. They are less likely to browse, may regard shopping as unnecessary and often spend less on any single journey due to their high frequency of travel.

By segmenting their customer base and providing a focused range of shopping facilities, the aim has been to offer a credible, commercial proposition that generates a consistent income stream for the retailer as well as the airport authority. The above activities represent a series of proactive initiatives designed to offset the decline of duty and tax-free sales, static aeronautical revenues and intense market competition. The significance of these non-aeronautical revenues to many airports means that there is a requirement for detailed research into consumer purchasing patterns and motives. 


\section{Methodology}

If as the literature suggests segmentation remains a means by which an organisation can more effectively target its resources, then at the outset it is necessary to identify whether customers do actually exhibit different forms of behaviour. In the context of this study, the primary question is whether it is possible to segment different categories of travelling passenger based upon an a priori system of classification.

The research project was undertaken with the full support of the airport authority and the findings were designed to both extend our conceptual understanding of the segmentation process as well as assist with the commercialisation strategy that was on-going. In particular it was hoped that the results could directly inform the segmentation strategy that was being developed by the airport authority. While there was substantial anecdotal evidence as to the spending patterns of different passengers, this study was the first attempt to both record how travellers allocated their pre-flight time and link this to shopping behaviour across all commercial areas. Access was therefore provided to secondary data that detailed the historical and current development of the airport as well as its management of aeronautical and non aeronautical activities.

The empirical research took place over a seven day period. The airport itself operates out of a single terminal building and handles approximately 16 million passengers a year. All flights depart through one of three piers (A, B or C). As the focus was upon the behaviour of individuals who were actually travelling, all the fieldwork was undertaken on the restricted, 'airside' (after passport control) of the airport. The commercial airside area comprises shops, 
restaurants and bars. On the 'landside' (before passport control) the commercial area is adjacent to arrivals and is focused upon the needs of those waiting to meet passengers. There were a small number of retailers in this area including a newsagent, a florist and a confectioner. This commercial area represented a small percentage of total retail sales (less than 5\%), was not targeted at the travelling passenger and was considered to be outside the remit of the research. The 'airside' commercial area was divided into three areas. The majority of commercial facilities are in a central location immediately after the security / 'friskem' checks. This represents the primary area for generating retail revenues. In addition, there were the two smaller shopping areas with limited retail provision adjacent to departure piers $\mathrm{A}$ and $\mathrm{B}$.

The research used non-probability convenience sampling. Having passed through the security area, a passenger was selected by one of the researchers and subsequently followed. All his / her activities were detailed and physically recorded on a tracking log (at no point did the individual know that they were being observed). By following an individual on their journey through the airport, the actual behaviour of the passenger could be recorded. The data that were gathered included the total time spent in the commercial areas, the amount of time spent shopping, eating and drinking and the time spent on other activities (e.g. using the telephone, looking at the flight information monitor etc). In addition, it was possible to identify the shopping behaviour of each individual and record the number of shops visited, the time spent in each outlet and whether or not the individual made a purchase. The use of observational techniques as a research methodology is not new (Hicks and Kohl, 1955; Wells and LoSciuto, 1966) and has been used in previous studies of both segmentation and tenant placement (Brown, 1992; Sinha and Uniyal, 2004). 
Once each passenger had passed through the commercial areas of the airport and had arrived at their departure gate, the next phase of the research was to interview each individual face to face. This quantitative survey provided further information on the demographics of the respondents, their reasons for travel, the duration of their visit, what they had purchased, their motives for purchasing, as well as general views on the commercial facilities within the airport. Only those passengers who were both tracked and agreed to be interviewed are included in this paper.

The questionnaire was first piloted and 301 passengers subsequently included in the research. It is acknowledged that this remains a relatively small number of interviewees given the total number of passengers travelling through the airport. Moreover by confining the research to a single week in August also restricts the extent to which any findings can be generalised.

These limitations are acknowledged in the subsequent discussions. A profile of respondents is provided in Table One.

Table One about here

\section{Understanding Passenger Behaviour: Research Findings}

The secondary data provided by the airport confirmed an ongoing process of commercial expansion and mirrored a strategy common amongst many European airport authorities. Over the past decade, there had been a conscious attempt to expand both the number of retailers operating and the product ranges on offer. The objective had been to re-position the airport as a shopping destination rather than a location to purchase 'traditional' airport products (i.e. liquor and spirits, tobacco and perfume and cosmetics). 
The first objective of the research was to determine the total time an individual spent in the commercial area of the airport. Table Two highlights considerable variations in passenger behaviour. For example, seven individuals passed through the commercial area without stopping, while one individual spent a total of 104 minutes on different activities. The average time that an individual spent in the commercial area was approximately 33 minutes.

Table Two about here

While Table Two provides a broad summation of the total time spent in the commercial area, it does not provide any indication of the types of activity undertaken. The next stage of the research identified how individuals allocated their time prior to departure. Understanding how passengers utilised their time is of particular importance in a retail context as Soars (2009) notes a direct link between dwell time and an individual's propensity to make a purchase (see also Torres et al., 2005 and Castillo-Manzano, 2010). Once a passenger entered the commercial area, the research recorded the amount of time each person spent shopping, eating and drinking and undertaking non commercial activities (phoning, using WC, asking directions etc). Table Three illustrates that while over half (56.5\%) of all passengers did use the cafe and restaurant facilities in the airport, just over $12 \%$ undertook no shopping activity.

Table Three about here 
On average $61.5 \%$ of respondents time was spent shopping $(\bar{x}=20.3$ minutes $)$, followed by $27 \%$ of the time in the airports bars and restaurants $(\bar{x}=9$ minutes $)$. Over $80 \%$ of respondents spent less than 5 minutes undertaking non-commercial activities ${ }^{\mathrm{ii}}(\bar{x}=3.4$ minutes). The research also identified a strong positive correlation between the amount of time an individual spent in the commercial area and the amount of time shopping (.731 sig.000). From an airport perspective such a finding helps eliminate the notion that passengers who are in the commercial area are undertaking activities unrelated to retail. The results indicate that while passengers are in the commercial area the majority are either actively shopping or using the bars and restaurants.

The next stage of the research was to examine respondents shopping behaviour. Passengers were tracked and recorded against a variety of criteria including the number of shops they visited, the length of time spent in each store, whether a purchase was made and whether individuals re-visited a store more than once. The research revealed that over half $(51.5 \%)$ of respondents visited more than two retail outlets with respondents visiting on average three stores. From the data it was also possible to calculate that on average, customers spent just over six and a half minutes in each store. Interestingly the total number of re-visits (the respondents returning to a store more than once) was low. Only 12 cases were noted across 301 respondents. This reinforces previous research (Freathy and O'Connell, 1998) that identified an unwillingness amongst passengers to retrace their steps or deviate from the main route to the departure gate (see also Geuens et al., 2004). The research noted that only 43 respondents did not make some form of purchase while in the commercial area over half $(51.5 \%)$ made more than one. The average number of transactions was 1.75 , which resulted in the airport having a penetration rate $\mathrm{in}^{\mathrm{iii}}$ of just over $85.7 \%$. 
Having identified the aggregate pattern of shopping behaviour amongst travelling passengers, the third stage of the research was to identify whether any significant differences existed across a number of dependent variables. Altogether eleven different variables ${ }^{\text {iv }}$ were analysed using Chi squared to determine whether any significant relationship could be identified as influencing passenger behaviour within the airport.

The results would suggest that the gender, the composition of the group, the frequency of travel, the purpose of travel, the duration of the visit and the number of flights taken in a twelve month period, all influence the behaviour of individuals while in the commercial area.

For example, a significant difference was noted in the time male and female passengers spent in the commercial area of the airport. While $36 \%$ of men spent less than 20 minutes in the commercial area, only $24 \%$ of women spent an equivalent time. At the other extreme, of the total number of passengers who spent more than one hour in the commercial area, $37 \%$ were males and $63 \%$ were females. Further gender differences were also noted in the amount of time actually spent shopping. The research revealed that $46 \%$ of males spent less that 10 minutes shopping, compared to only $24 \%$ of females. While research into gender as a determinant of shopping behaviour is not new (Buttle, 1992; Qualls, 1987), debate exists as to whether males and females exhibit different patterns of behaviour in an airport environment. While some studies maintain that gender has only a limited role in helping to understand passenger behaviour (Castillo-Manzano, 2010), this research did not support this finding and reinforces the work of Graham (2008) and Geuens et al. (2004).

A significant association was also noted between the composition of the travelling group, the period spent in the commercial area and the time shopping. For example, almost one third of 
passengers who were travelling alone spent under 10 minutes in the commercial area. This compares to $5.4 \%$ if travelling in a group without children and $7.5 \%$ if travelling in a group with children. Such findings reinforce previous research that has highlighted the different patterns of shopping behaviour based upon the number of people travelling and the group composition (Castillo-Manzano, 2010). Luo (2005) for example notes how purchasing behaviour is influenced by the composition and cohesiveness of the group and motivated by an individual's desire to comply with the social norm.

Individuals on business were found to travel more frequently, spend less time in the commercial area and less time actually shopping. For example, $60 \%$ of business passengers spent under 20 minutes in the commercial area compared to only $22 \%$ of those travelling for pleasure. No business traveller made more than two purchases, whereas $34 \%$ of passengers travelling for pleasure made three or more purchases.

Finally, a significant association was noted between a respondents behaviour and the duration of their trip. For example, $70 \%$ of individuals travelling out and returning within a day spent less than half an hour in the commercial area (in contrast, $61 \%$ of those travelling for more than 8 days spent over 50 minutes in the commercial area). Similarly only $6 \%$ of passengers on a day return spent more than 10 minutes actually shopping, this compared to $76 \%$ of those passengers travelling for more than one day. In addition, only two passengers on a day trip visited more than two shops and no individual in this category made more than two purchases.

One explanation put forward to explain these findings is that individuals on business, travel more regularly, may often be familiar with both the layout and product offer in the airport 
and therefore need to spend less time browsing for the products they require. Moreover because of the frequency they travel they are less inclined to make a purchase. This was supported by the finding that the overwhelming majority of day return passengers (89\%) were travelling for business rather than pleasure. The notion that the mood of the purchaser influences the shopping intention is not new (Swinyard, 1993), while Baron and Wass', (1996) typology of the leisure traveller identified distinct behavioural traits when shopping in an airport environment. They identified that passengers about to embark upon a leisure trip tended to make 'self-treat' or 'self-indulgent' purchases and that rationale, utilitarian forms of purchasing made way for more hedonistic shopping activities (see also Fernie, 1995). However despite displaying a lower propensity to purchase products, business travellers continue to represent an important segment for the airport retailer. As Freathy and O'Connell (1998) noted, despite shopping infrequently, when business passengers do purchase, they often spend above the average transaction value and purchase higher ticket, higher margin items.

Having identified that different passenger segments display different patterns of behaviour within the airport, the next stage was to understand their motivations for shopping. In particular, were individuals primarily shopping for themselves or for gifts and whether the items were planned or bought on impulse. In its recording of product sales, the airport authority placed each passenger's purchase into one of fourteen different categories ${ }^{\mathrm{v}}$ and it was noted that 258 $(85.7 \%)$ respondents undertook at least one airside transaction. Altogether just under 500 separate purchases were made by the respondents with more than twice as many transactions being for personal use $(n=343)$ rather than for a gift $(n=154)$. The average spend for personal purchases and gifts was similar (€26.52 and $€ 26.84$ respectively) and no significant difference was noted between the reason for purchase and each of the passenger segments. 
The research therefore examined whether these personal and gift purchases were bought on impulse or planned prior to arrival at the airport.

Significant previous research has been undertaken in the area of impulse purchasing behaviour. Over four decades ago, Kollat and Willett (1967) noted a growing body of work that sought to measure the incidence of impulse purchasing, identify the propensity of products to be bought and the influence of variables such as shelf space and location upon behaviour. However as Crawford and Melewar (2003) note there has been only limited research into the impulse behaviour of travelling passengers. Baron and Wass' (1997) examination of leisure shoppers in an airport environment identified only limited impulse shopping activity. They noted that the majority of passengers in their survey had undertaken some form of sequential decision making and many respondents arrived at the airport knowing what they wanted to purchase. Understanding whether there has been an increase in 'unplanned, non necessity purchases' (Bayley and Nancarrow, 1998:99) is a precursor to the formulation of an appropriate marketing strategy. In the context of this research, having an understanding of this type of purchase behaviour may influence the airport's choice of tenant mix as well as help determine the most suitable types of merchandise to stock (Table Four).

Table Four about here

It would appear that the majority of retail purchases made by passengers are planned in advance and this remains the case whether the item is for personal use or for a gift. While a slight variation was noted in that gift items were more likely to be an impulse item, the research revealed that over $72 \%$ of all transactions made in the commercial area were planned 
and in terms of actual spending accounted for $65 \%$ of total revenues. When spending patterns were disaggregated, the average planned spend was higher in 10 of the 14 product categories. Interestingly however, impulse buys accounted for the largest average spend in three categories where the transaction values were highest (Spirits, Perfume/Cosmetics and Jewellery). Importantly in the context of this research, when compared across the segments, no significant differences were noted in the purchase of impulse/planned items.

Two issues may be derived from these findings, first, despite passengers planning the majority of their purchases, they are still willing to buy specific larger ticket items on impulse. Secondly, there was no evidence to suggest different passenger segments had a greater likelihood of making an impulse purchase. However as Crawford and Melewar (2003) noted, the relatively low incidence of unplanned purchases provides significant future growth opportunities and encourages the development of an impulse purchasing strategy for airport retailers.

The high retail penetration rate meant that only 43 respondents did not make a purchase while passing through the airport. To date there has been only limited academic research into why passengers choose not to shop when travelling. Some such as Rowley and Slack (1999) draw attention to the importance of the service environment in order to stimulate sales, while Barron and Wass (1997) noted that the main reason for not buying was that passengers simply 'did not require anything'. This latter reason was the primary finding in this research (Table Five). Moreover, when cross tabulated against the purpose of the journey, the majority of those individuals who did not need anything were travelling on business. Again this reinforces previous research that identified business passengers travelled more 
frequently, had greater opportunities to shop in the airport and were less likely to purchase goods on each visit (Freathy and O'Connell, 2000).

Table Five about here

Overall, the face to face interviews provided an encouraging set of findings for the airport. The majority of respondents agreed that it was a convenient location to purchase products and the current tenant mix was seen to offer a wide range of goods and services. Of some concern was the fact that the airport was not necessarily viewed as providing good value nor was it seen as having a particularly strong assortment of international designer brands and labels. Also, reinforcing Rowley and Slack's (1999) research into the importance of the servicescape, some respondents noted that the airport was too crowded to shop. The influence of crowding upon an individual's propensity to purchase has previously been identified (Penz and Hogg, 2011; Whitting, 2009) and this finding may partly be explained by the research being conducted during August, a peak travelling month for passengers. In addition, the airport had experienced a $22 \%$ growth in passenger numbers over the previous four years. While the retail infrastructure had also expanded during this time, passenger dissatisfaction may in part, be attributable to the pressures caused by this growth.

\section{Discussion and Conclusions}

Through combined observational research and face to face interviews, this paper has attempted to identify the behaviour of departing passengers on the airside of an international airport. It has delineated travellers using a priori sub segments, detailed the commercial and non commercial activities that they undertake and investigated consumer's opinions of 
the shopping environment. As Hollywood et al. (2007) note, understanding such behaviour can directly inform an organisation's current and future business strategy. This final section will consider the broader implications of these findings at both a managerial and theoretical level and comment upon the efficacy of segmentation as a means of achieving strategic marketing outcomes.

It was noted at the beginning of this paper that the airport authority was attempting to develop a segmentation strategy which in turn could help achieve a broader series of commercial objectives. The growth in passenger numbers and the expansion of retail space required a strategy that was, in part, predicated upon a better understanding of consumer shopping behaviour. It would appear that on the evidence of the findings presented here, that an $a$ priori approach to market segmentation can offer organisations a practical means of classifying and managing customer groups (Weinstein 2004). This is not to argue that it remains the only approach, nor does it necessarily indicate that it is the most appropriate form of consumer categorisation. However as Dolincar and Lazarevski (2009) note it continues to represent a cost effective business practice that does not cause the same implementation difficulties as other forms of segmentation (see also Hassan and Craft 2005).

From a managerial perspective such findings would indicate that a market segmentation strategy can be developed in an airport using broad based, pre-determined categories. The research identified significant differences in behaviour across a number of passenger segments. Decisions on how to better respond to different types of traveller, whether to broaden the range of impulse / planned items or increase the number of gift / personal products may in part be derived from the information gathered. Understanding the different browsing habits and dwell times of travellers also allows the airport to make informed 
decisions about managing passenger flows and improving communications (for example, through the provision of improved signage and information monitors). However as Sausen et al (2005) note the inherent value of segmentation extends beyond the identification of consumer group needs and towards the achievement of broader strategic and marketing goals. As such, the efficacy of the exercise will be dependent upon the extent to which the airport authority can encompass such findings into a holistic strategy that extends beyond the narrower confines of operational segmentation. As was noted previously, a failure to view market segmentation as integral to the achievement of an organisation's wider corporate objectives, will limit the overall value of such an exercise.

At the same time the findings from this study also underline a potential weakness in the $a$ priori approach. While Hassan and Craft (2005) note that the value of segmentation lies in its ability to evaluate key consumer groups who display homogenous tendencies, this study illustrates the dangers of intuitively categorising segments based upon a set of broad based macro level variables. While the attraction of using this form of segmentation lies in its relative simplicity and straightforward application, classifying individuals on the basis of observable behaviour provides only a partial understanding of their actual pattern of shopping. While it was possible to identify significant differences in the way in which passengers allocated their time in the commercial area, few differences were subsequently noted when it came to purchase motivation. This highlights the danger of categorising different segments based upon an incomplete understanding of actual behaviour. Focusing upon one specific part of the passenger experience (e.g. time spent browsing) could lead to the creation of sub-segments that fail to justify the allocation of marketing resources (Kotler 1999). 
The findings in this paper therefore provide a partial picture of passenger activity and a more complex pattern of behaviour may yet be identified through further research and analysis. For example, while women spend longer shopping in the commercial area and visit more shops, what they purchase and how much they spend has yet to be investigated. Such information remains crucial in not only creating a holistic understanding of behaviour but ultimately serving to confirm or deny the legitimacy of the categories themselves.

Moreover, gathering and incorporating such information into the airport's overall planning process has the potential to extend the importance of market segmentation and move it beyond a profiling exercise. It can facilitate a strategic assessment of the relative priority of each segment and allow resources to be allocated in a more informed way (Dibb and Simkin 2010; Sausen et al 2005). In turn, this would suggest that the primary benefits are afforded to an organisation when strategic market segmentation is viewed as an iterative rather than a linear process.

At a theoretical level, the findings from this paper imply a continued disjuncture between academic theory and practice noted by previous research (Crittenden et al 2002; Dibb and Simkin 2010; Sausen et al 2005). External market pressures derived from the legislative provisions relating to fiscal harmonisation and the pressure upon rapid commercial expansion undermines the notion that organisations can necessarily comply with the requirement of traditional normative segmentation models. The conventional segmentation - targeting positioning sequence would appear to have only limited relevance in this rapidly expanding market and reinforces the observation that the 'real world' has often been ignored when developing theories of market segmentation. 
Newhouse (2010) identifies issues such as the state of security, industrial action, natural disasters (such as the volcanic ash cloud) and the exchange rate as all influencing an individual's propensity to buy. These factors combined with the abolition of duty and tax free sales on intra EU flights have served to create a series of economic imperatives. Not least the need to maintain commercial income in the face of declining aeronautical revenues. Such pressures deny organisations the luxury of time and limit their ability to follow sequential models such as that identified by Hlavacek and Reddy (1986). While a staged process of segment identification, segment qualification and segment attractiveness may be desirable, in practice, commercial pressures may require a more ad hoc and flexible approach. This issue was demonstrated in the context of this research, resource and time constraints meant that existing variables used to record passenger numbers were used and the ability separately derive, operationalise and appraise alternative segments or consider alternative approaches to market segmentation, was not afforded.

This is not to deny the importance of each component nor does it undermine the value of following such a process. It does however highlight the importance of understanding the practical constraints imposed upon an organisation by business need. Similarly the inclusion of segmentation variables such as Entry Point and Security reinforce the notion that some segments may be intuitively or artificially constructed and highlight the importance of managerial discretion in segmentation studies (Quinn 2009; Wedel and Kamakura 2000) .

In conclusion therefore, this paper has identified that different types of passenger exhibit different patterns of behaviour while on the airside of an international airport. It has considered whether these travellers can be segmented using an a priori method and the issues involved in this form of categorisation. The research confirms the applicability of a broad 
based market segmentation strategy although it highlights the importance of taking a holistic approach to ensure a relevant system of classification. Moreover it suggests that the disjuncture between segmentation theory and practice may not be a failure of understanding, rather a reflection of commercial pressures and business need. 


\section{References}

ACI (2007). Position brief, October, Airports Council International, Switzerland.

Alfansi, L. and Sargeant, A. (2000). 'Market segmentation in the Indonesian banking sector: the relationship between demographics and desired customer benefits', International Journal of Bank Marketing, 18(2), 64-74.

Ansell, J., Harrison, T., Archibald T. (2007). 'Identifying cross-selling opportunities, using lifestyle segmentation and survival analysis', Marketing Intelligence \& Planning, 25(4), 394410 .

BAA (2010). http://www.baa.com/portal/page/XYZRetailB2B/ last accessed 4th October 2010.

BAA (2007). Terminal Five Fabulous Food for all http://www.heathrowairport.com/portal/page/Heathrow\%5EGeneral\%5EOur+business+and+ community\%5EMedia+centre\%5EPress+releases\%5EResults/47290f34cdd33110VgnVCM1 0000036821c0a__a22889d8759a0010VgnVCM200000357e120a__/last accessed August 19th 2011.

Baltas G. (2003) 'A combined segmentation and demand model for store brands'. European Journal of Marketing 37 (10) 1499-1513

Baron, S., Wass, K. (1996). 'Towards an understanding of airport shopping behaviour', International Review of Retail, Distribution \& Consumer Research, 6(3), 301 - 323.

Barry, J. and Weinstein, A. (2009) Business psychographics revisited: from segmentation theory to successful marketing practice, Journal of Marketing Management, 25, (3-4) pp. 315-340.

Bayley, G., Nancarrow, C. (1998). 'Impulse purchasing: a qualitative exploration of the phenomenon', Qualitative Market Research: An International Journal 1(2) 99 -114.

Bickert, J. (1997) 'Cohorts II: a new approach to market segmentation' Journal of Consumer Marketing, 14, 362-380

Bonoma, T., and Shapiro, P. (1984). 'Segmenting the Industrial Market', D.C. Heath Company, Lexington, MA.

Brown, S. (1992). 'Tenant Mix, Tenant Placement and Shopper Behaviour in a Planned Shopping Centre', The Service Industries Journal, 12(3), 384 - 403.

Buttle, F. (1992). 'Shopping motives constructionist perspective', Services Industries Journal, 12, 349-67. Cahill, D. (1997). 'Target marketing and segmentation: valid and useful tools for marketing' Management Decision, 35, 10-14. 


\section{Cahill, D. (1997) 'Target marketing and segmentation: valid and useful tools for marketing' Management Decision, 35, 10-14}

Castillo-Manzano, J. (2010) Determinants of commercial revenues at airports: Lessons learned from Spanish regional airports Tourism Management, 31, (6), 788-796.

Chetthamrongchai, P., Davies, G. (2000). 'Segmenting the market for food shoppers using attitudes to shopping and to time', British Food Journal, 102(2), 81 - 101.

Cheung, A., Yuen, T., Yuen, C. and Cheng, Y. (2010) Promoting Hong Kong's higher education to Asian markets Market segmentations and strategies, International Journal of Educational Management, Vol.24, No.5 pp: 427-447.

Chiang, K., and Dholakia, R. (2003). 'Factors Driving Consumer Intention to Shop Online: An Empirical Investigation', Journal of Consumer Psychology. 13(1-2), 177-183.

Claston, R. (1995). 'Birth Order as a market segmentation variable', Journal of Consumer Marketing 12, 22-39.

Crawford, G., Melewar, T. (2003). 'The importance of impulse purchasing behaviour in the international airport environment'. Journal of Consumer Behaviour, 3(1), 85-98.

Crittenden, V.L., Crittenden, W.F., \& Muzyka, D.F. (2002). Segmenting the business-tobusiness marketplace by product attributes and the decision process. Journal of Strategic Marketing, 10, (1) 3-20.

Cuthbertson R. and Laine A. (2004) 'The role of CRM within retail loyalty marketing'. Journal of Targeting, Measurement and Analysis for Marketing, 12, (3) 290-304

DFNI (2010). Liverpool airport to expand airside retail offer http://www.dfnionline.com/article/Liverpool-airport-to-expand-airside-retail-offer1859743.html last accessed August 19th 2011.

Dholakia, R. (1999). 'Going shopping: key determinants of shopping behaviours and motivations', International Journal of Retail \& Distribution Management, 27(4),154 - 165.

Dibb, S. (1998). 'Market segmentation: strategies for success', Marketing Intelligence and Planning 16, 394-406.

Dibb, S., Simkin, L. (1991). 'Targeting, segments and positioning', International Journal of Retail and Distribution Management, 19(3), 4-10.

Dibb, S. and Simkin, L. (2009) 'Implementation rules to bridge the theory/practice divide in market segmentation', Journal of Marketing Management, 25, (3 \& 4), pp. 375 - 396.

Dibb, S. and Simkin, L. (2010) Judging the quality of customer segments: segmentation effectiveness Journal of Strategic Marketing, 18, (2), 113-131 
Dibb, S., Wensley, R. (2002). 'Segmentation analysis for industrial marketing: problems of integrating customer requirements into operations strategy', European Journal of Marketing, $36(1 / 2), 231-251$.

Doganis, R. (2009). 'Flying off course, airline economics and marketing 4th edition Routledge', London.

Dolnicar, S. (2004). 'Beyond "Commonsense Segmentation": A Systematics of Segmentation Approaches in Tourism', Journal of Travel Research 42(3), 244-250.

Dolnicar, S. and Lazarevski, K. (2009) 'Methodological reasons for the theory/practice divide in market segmentation', Journal of Marketing Management, 25: 3, 357 - 373.

Fernie, J. (1995). 'The coming of the fourth wave: new forms of retail out-of-town development', International Journal of Retail \& Distribution Management, 23(1), 4 - 11.

Firat, A., Shultz, C. (1997). 'From segmentation to fragmentation: markets and marketing strategy in the postmodern era', European Journal of Marketing, 31(3/4), 183-207.

Foedermayr, E., Diamantopoulos, A. (2008). 'Market Segmentation in Practice: Review of Empirical Studies, Methodological Assessment, and Agenda for Future Research'. Journal of Strategic Marketing, 16(3), 223-265,

Forgas, S., Moliner, M., Sánchez, J., Palau, R. (2010). 'Antecedents of airline passenger loyalty: Low-cost versus traditional airlines', Journal of Air Transport Management 16(4), 229-233.

Freathy, P., O'Connell, F. (1998). European Airport Retailing. London: Macmillan.

Freathy, P., O'Connell, F. (1998) 'A Typology of European Airport Retailing' Service Industries Journal 19 (3) 119-134

Freathy, P., O'Connell, F. (2000). 'The creation of orientation and the segmentation of purpose: examples from the European airport sector', Marketing Intelligence and Planning, 18(3) 102-111.

Garcia, E. Royo-Vela, M. (2010). 'Segmentation of low-cost flights users at secondary airports' Journal of Air Transport Management 16(4), 234-237.

González, A. and Bello, L. (2002) 'The construct "lifestyle" in market segmentation: The behaviour of tourist consumers'. European Journal of Marketing 36 (1) 51-85

Graham, A. (2008). Managing Airports: An international perspective, Third Edition. Oxford Butterworth - Heinemann.

Green, P.E., Krieger A.M. (1991). 'Segmenting markets with conjoint analysis', Journal of Marketing, 55, 20-31.

Geuens, M., Vantomme, D., Brengman, M. (2004). 'Developing a typology of airport shoppers', Tourism Management, 25(5), 615-622. 
Harrison, T. (1995). 'Segmenting the market for retail financial services', The International Review of Retail, Distribution and Consumer Research, 5(3), 271 - 286.

Hassan, S., Craft, S. (2005). 'Linking global market segmentation decisions with strategic positioning options', Journal of Consumer Marketing 22(2), 81-89.

Hicks, J.W., Kohl, R. (1955). 'Memomotion study as a method of consumer study', Journal of Marketing 20, 168-170.

Hlavacek, J.D., \& Reddy, N.M. (1986). Identifying and qualifying industrial market segments. European Journal of Marketing, 20, 8-21.

Hoek, J., Gendall, P., Esslemont, D. (1996). 'Market segmentation: a search for the Holy Grail?', Journal of Marketing Practice: Applied Marketing Science, 2(1), 25-34.

Hollywood, L., Armstrong, G., Durkin, M. (2007). 'Using behavioral and motivational thinking in food segmentation', International Journal of Retail \& Distribution Management, 35(9), 691-702.

Humphreys, I., Francis, G. (2002). ‘Airport Privatization', British Economy Survey, 31(2), 51-56.

Kangis, P., O'Reilly, D. (2003). 'Strategies in a Dynamic Market Place: A Case Study in the Airline Industry', Journal of Business Research, 56, 105-111.

Kim H. and Shin, J. (2001) A contextual investigation of the operation and management of airport concessions ,Tourism Management 22 149-155

Kımıloğlu, H., Nasır, V. and Nasır, S. (2010) Discovering behavioral segments in the mobile phone market, Journal of Consumer Marketing, Vol. 27 No. 5 pp: 401-413.

Kinra, N. (1997). 'The communicative effectiveness of ethnically oriented advertising' International Journal of Advertising, 16, 221-240.

Kollat, D., Willett, R. (1967). 'Customer Impulse Purchasing Behaviour', Journal of Marketing Research, 4(1), 21-31.

Kotler, P. (1999). 'Marketing Management: Analysis, Planning, Implementation and Control, 9th Edition', Prentice-Hall International (UK) Limited, London.

Larrew, T. (1998). 'Disney Vacation Club shares the magic with stronger acquisition promotions' Direct Marketing http://www.allbusiness.com/marketingadvertising/segmentation-targeting/665702-1.html last accessed August 19th 2011. Leisen, B. (2001) 'Image segmentation: the case of a tourism destination'. Journal of Services Marketing 15 (1) 49-66

Luo, X. (2005). 'How Does Shopping With Others Influence Impulsive Purchasing?', Journal of Consumer Psychology, 15(4), 288-294. 
Mäenpää, K. (2006). 'Clustering the consumers on the basis of their perceptions of the Internet banking services', Internet Research, 16(3) 304-322.

Magson, N.and Dipple, D. Time to fly: An approach to segmentation and modelling customer dynamics in the travel sector The Journal of Database Marketing \& Customer Strategy Management, Vol. 11, No.4, pp. 299-318.

Malighetti, P., Paleari, S. Redondi, R. (2009). 'Pricing strategies of low-cost airlines: The Ryanair case study', Journal of Air Transport Management, 15(4), 195-203.

Marcus, C. (1998). 'A practical yet meaningful approach to customer segmentation', Journal of Consumer Marketing 15, 494-501.

Moodie, M. (2010). 'BAA's Brian Woodhead on building knowledge and partnerships', Moodie Report online http://www.moodiereport.com/document.php?c_id=20\&doc_id=23781 last accessed 11th October 2010.

Moschis, G., Euehun, L., Mathur, A. (1997). 'Targeting the mature market: opportunities and challenges', Journal of Consumer Marketing, 14, 282-294.

Moschis G., Curasi, C. and Bellenger D. (2004) 'Patronage motives of mature consumers in the selection of food and grocery stores'. Journal of Consumer Marketing 212123 -133

Newhouse, D. (2010). 'Heathrow makes strong retail start to 2010', Travel Retail Executive News Digest, http://www.trend-news.com/default.asp?newsid=8031 last accessed 11th October 2010.

Newman, S., Lloyd-Jones, T. (1999). ‘Airport and Travel Termini Retailing: Strategies, Trends and Market Dynamics', Financial Times, London, 24.

Omar, O., Kent, A. (2001). 'International airport influences on impulsive shopping: trait and normative approach', International Journal of Retail \& Distribution Management, 29(5), 226-235.

Orth U.R., McDaniel M., Shellhammer T. and Lopetcharat K. (2004) 'Promoting brand benefits: the role of consumer psychographics and lifestyle'. Journal of Consumer Marketing, 21 (2) 97-108

Paço, A., Raposo, M. (2009). "'Green” segmentation: an application to the Portuguese consumer market', Marketing Intelligence \& Planning, 27(3), 364-379.

Palumbo, F., Teich, I. (2004). 'Market segmentation based on level of acculturation', Marketing Intelligence \& Planning, 22(4), 472-484.

Penz, E., and Hogg, M, (2011). 'The role of mixed emotions in consumer behaviour: Investigating ambivalence in consumers' experiences of approach-avoidance conflicts in online and offline settings', European Journal of Marketing, 45(1/2) 104 - 132.

Piercy, N., and Morgan, N. (1993). 'Strategic and operational market segmentation: a managerial analysis', Journal of Strategic Marketing, 1(2), 123-40. 
Pitt, M. (2001). 'Strategic Direction in the Airport Business: Enabling or Disabling?', Facilities. 19(3/4).

Pitt, M., Brown, A. (2001). 'Developing a strategic direction for airports to enable the provision of services to both network and low-fare carriers' Facilities 19(1).

Qualls, W. (1987). 'Household decision behavior: the impact of husbands' and wives' sex role orientation', Journal of Consumer Research, 14, 264-79.

Quinn, L. (2009) 'Market segmentation in managerial practice: a qualitative examination', Journal of Marketing Management, 25: 3, 253 - 272.

Quinn, L., Hines, T., Bennison, D. (2007). 'Making sense of market segmentation: a fashion retailing case', European Journal of Marketing 41(5/6), 439-46.

Rao, C. Wang, Z. (1995). 'Evaluating alternative segmentation strategies in standard industrial markets' European Journal of Marketing, 29, 58-76.

Reisenwitz, T., Iyer, R. (2007). 'A comparison of younger and older baby boomers: investigating the viability of cohort segmentation', Journal of Consumer Marketing 24(4) 202-213.

Riquier, C., Luxton, S., Sharp, B. (1997). 'Probabilistic segmentation modelling', Journal of the Market Research Society, 39, 571-588, Direct Marketing, 60, 54-56.

Rowley, J., Slack, F. (1999). 'The retail experience in airport departure lounges: reaching for timelessness and placelessness', International Marketing Review, 16(4/5), 363-376.

Ruiz, J., Chebat, J., Hansen, P. (2004). 'Another trip to the mall: a segmentation study of customers based on their activities', Journal of Retailing and Consumer Services, 11(6), 333350 .

Sarabia, F. (1996). 'Model for market segments evaluation and selection' European Journal of Marketing, 30, 58-75.

Saunders, J. (1995). 'Invited Comment on the Market Segmentation Content of 'A Critical Review of Research in Marketing', British Journal of Management, 6(6), 89 -91.

Sausen, K., Tomczak, T. and Herrmann, A. (2005) 'Development of a taxonomy of strategic market segmentation: a framework for bridging the implementation gap between normative segmentation and business practice', Journal of Strategic Marketing, 13 151-173.

Segal, M., Giacobbe, R. (1994). 'Market Segmentation and Competitive Analysis for Supermarket Retailing', International Journal of Retail \& Distribution Management, 22(1), $38-48$.

Sinha, P., Uniyal, D. (2005). 'Using observational research for behavioural segmentation of shoppers'. Journal of Retailing and Consumer Services 12(1), 35-48. 
Smith, W. (1956). 'Product differentiation and market segmentation as alternative marketing strategies', Journal of Marketing, 21, July, 3-8.

Soars, B. (2009). 'Driving sales through shoppers' sense of sound, sight, smell and touch', International Journal of Retail \& Distribution Management 37(3), 286-298.

Souiden, N. (2002). 'Segmenting the Arab markets on the basis of marketing stimuli', International Marketing Review, 19(6) 611-636.

Sudbury, L., Simcock, P. (2009). 'A multivariate segmentation model of senior consumers', Journal of Consumer Marketing, 26(4), 251-262.

Swinyard, W. (1993). 'The Effects of Mood, Involvement, and Quality of Store Experience on Shopping Intentions', The Journal of Consumer Research, 20(2) 271-280.

Torres, E., Domınguez, J. S., Valdes, L., \& Aza, R. (2005). Passenger waiting time in an airport and expenditure carried out in the commercial area. Journal of Air Transport Management, 11, 363-367.

Tractinsky N. and Lowengart O. (2003) 'E-retailers' competitive intensity: A positioning mapping analysis'. Journal of Targeting, Measurement and Analysis for Marketing, 12,(2) $114-136$

Trinh, G., Dawes, J. and Lockshin, L. (2009) Do product variants appeal to different segments of buyers within a category?, Journal of Product \& Brand Management Vol.18, No. 2.pp.95-105.

Rafiq, M. and Fulford, H. (2005) Loyalty transfer from offline to online stores in the UK grocery industry, International Journal of Retail \& Distribution Management, Vol. 33, No.6, pp. $444-460$

Ruiz, J., Chebat, J. and Hansen, P. (2004) Another trip to the mall: a segmentation study of customers based on their activities, Journal of Retailing and Consumer Services Vol. 11, No.6, pp 333-350.

Vasigh, B., Erfani, R. and Miner, D. (2009). 'Evaluation of airport performance:

Public versus private ownership', The International Conference on Economics and Administration, Faculty of Administration and Business, University of Bucharest, Romania ICEA - FAA Bucharest, 14-15th November 2009.

Wells, W. And LoSciuto, L. (1966). 'Direct observation of shopper behaviour', Journal of Marketing, 3, 227-233.

Wedel, M., and Kamakura, W. (2000). Market segmentation: Conceptual and methodological foundations. Boston: Kluwer.

Weinstein, A. (2004). Handbook of market segmentation. New York: Haworth Press.

Wensley, R. (1995). 'A Critical Review of Research in Marketing'. British Journal of Management, 6(6) $63-83$. 
Whitting, A. (2009). 'Push, scream or leave: how do consumers cope with crowded retail stores?', Journal of Services Marketing, 23(7), 487 - 495.

Wind, Y. (1978). 'Issues and advances in segmentation research', Journal of Marketing Research, 15, 317-37.

Woo, K. (1998). 'Using quality perceptions to segment customers in services', Marketing Intelligence and Planning, 16, 418-424.

Wright, M., (1996). 'The dubious assumptions of segmentation and targeting', Management Decision, 34, 18-24.

Ziliani C. and Bellini S. (2004) 'From loyalty cards to micro-marketing strategies: Where is Europe's retail industry heading?'. Journal of Targeting, Measurement and Analysis for Marketing, 12,(3) 281-289 
Table 1: Profile of Respondents

\begin{tabular}{|c|c|c|c|}
\hline Characteristics & Category & $\begin{array}{c}\text { Passenger Profile } \\
\text { (n) }\end{array}$ & $\begin{array}{c}\text { Passenger Profile } \\
(\%)\end{array}$ \\
\hline \multirow[t]{2}{*}{ Entry Point } & Point A & 136 & 45.2 \\
\hline & Point B & 165 & 54.8 \\
\hline \multirow[t]{2}{*}{ Gender } & Male & 151 & 50.2 \\
\hline & Female & 150 & 49.8 \\
\hline \multirow[t]{4}{*}{ Security } & Frisked & 67 & 22.3 \\
\hline & Bag Searched & 36 & 12 \\
\hline & Both & 42 & 14 \\
\hline & Not stopped & 156 & 51.8 \\
\hline \multirow[t]{3}{*}{ Travel } & Alone & 96 & 31.9 \\
\hline & Group without children & 112 & 37.2 \\
\hline & Group with children & 93 & 30.9 \\
\hline \multirow[t]{7}{*}{ Airline } & Aer Lingus & 81 & 26.9 \\
\hline & Ryanair & 97 & 32.2 \\
\hline & BA & 19 & 6.3 \\
\hline & BMI & 14 & 4.7 \\
\hline & Aer Arran & 7 & 2.3 \\
\hline & Air France & 9 & 3 \\
\hline & Other & 74 & 24.6 \\
\hline \multirow[t]{3}{*}{ Departure Pier } & $\mathrm{A}$ & 142 & 47.2 \\
\hline & B & 106 & 35.2 \\
\hline & $\mathrm{C}$ & 53 & 17.6 \\
\hline \multirow[t]{4}{*}{ Purpose } & Business & 48 & 15.9 \\
\hline & Pleasure & 180 & 59.8 \\
\hline & Visiting friends \& relatives & 63 & 20.9 \\
\hline & Other & 10 & 3.3 \\
\hline \multirow[t]{4}{*}{ Duration } & 1 day & 23 & 7.6 \\
\hline & $2-7$ days & 126 & 41.9 \\
\hline & $8-14$ days & 127 & 42.2 \\
\hline & More than two weeks & 25 & 8.3 \\
\hline \multirow[t]{5}{*}{ Residence } & Ireland & 167 & 55.5 \\
\hline & Great Britain & 78 & 25.9 \\
\hline & Europe & 33 & 11 \\
\hline & North America & 12 & 4 \\
\hline & Other & 11 & 3.7 \\
\hline \multirow[t]{4}{*}{ Age } & Under 25 & 58 & 19.3 \\
\hline & $25-40$ & 157 & 52.2 \\
\hline & $40-55$ & 66 & 21.9 \\
\hline & $55+$ & 20 & 6.6 \\
\hline \multirow[t]{4}{*}{ Return Flights per Year } & Between 1 and 5 & 176 & 58.5 \\
\hline & Between 5 and 10 & 83 & 27.6 \\
\hline & Between 10 and 20 & 27 & 9 \\
\hline & More than 20 & 15 & 5 \\
\hline
\end{tabular}


Table Two: Total time spent in the airports commercial areas

\begin{tabular}{|c|c|c|}
\hline $\begin{array}{c}\text { Total } \\
\text { Time } \\
\text { (Minutes) }\end{array}$ & $\begin{array}{c}\text { Number of } \\
\text { Passengers }\end{array}$ & $\%$ \\
\hline $0-10$ & 44 & 14.6 \\
\hline $11-20$ & 47 & 15.6 \\
\hline $21-30$ & 61 & 20.3 \\
\hline $31-40$ & 58 & 19.3 \\
\hline $41-50$ & 40 & 13.3 \\
\hline $51+$ & 51 & 16.9 \\
\hline Total & 301 & 100 \\
\hline
\end{tabular}


Table Three: Activities undertaken while in the commercial area of the airport

\begin{tabular}{|l|l|l|l|l|l|l|l|l|}
\hline $\begin{array}{l}\text { Activity } \\
\text { Minutes }\end{array}$ & $\begin{array}{l}0 \\
(\%)\end{array}$ & $\begin{array}{l}1-10 \\
(\%)\end{array}$ & $\begin{array}{l}11-20 \\
(\%)\end{array}$ & $\begin{array}{l}21-30 \\
(\%)\end{array}$ & $\begin{array}{l}31-40 \\
(\%)\end{array}$ & $\begin{array}{l}41-50 \\
(\%)\end{array}$ & $\begin{array}{l}51+ \\
(\%)\end{array}$ & $\begin{array}{l}\text { Total } \\
(\mathrm{n})\end{array}$ \\
\hline $\begin{array}{l}\text { Total Time } \\
\text { Shopping }\end{array}$ & 12.3 & 22.9 & 21.9 & 19.9 & 13.3 & 5.6 & 4 & 301 \\
\hline $\begin{array}{l}\text { Total Time } \\
\text { Eating and } \\
\text { Drinking }\end{array}$ & 56.5 & 9.6 & 20.3 & 7.6 & 3 & 1.7 & 1.3 & 301 \\
\hline $\begin{array}{l}\text { Total time } \\
\text { on non- } \\
\text { commercial } \\
\text { activities }\end{array}$ & 27.2 & 69.4 & 3 & 0.3 & & & & 301 \\
\hline
\end{tabular}


Table Four: Total Number of Planned and Impulse Purchases cross-tabulated by reason for purchase

\begin{tabular}{|l|l|l|l|}
\hline & Planned & Impulse & Total \\
\hline Personal Purchase & $255(74 \%)$ & $88(26 \%)$ & 343 \\
\hline Gift Purchase & $104(68 \%)$ & $50(32 \%)$ & 154 \\
\hline Total & 359 & 138 & 497 \\
\hline
\end{tabular}


Table Five: The main reasons for not shopping at the airport (multiple responses permitted)

\begin{tabular}{|l|c|c|}
\hline & $\mathrm{n}$ & $\%$ \\
\hline Did not need anything & 34 & 35.6 \\
\hline $\begin{array}{l}\text { Did not have time to make } \\
\text { a purchase }\end{array}$ & 8 & 8.4 \\
\hline $\begin{array}{l}\text { Did not see anything } \\
\text { that I wanted }\end{array}$ & 8 & 8.4 \\
\hline No holiday money / budget left & 2 & 2.1 \\
\hline Airport too expensive & 10 & 10.5 \\
\hline $\begin{array}{l}\text { I had bought what I needed } \\
\text { Before I arrived at the airport }\end{array}$ & 4 & 4.2 \\
\hline Product that I wanted was sold out & 2 & 2.1 \\
\hline Product that I wanted was not sold at airport & 0 & 0 \\
\hline $\begin{array}{l}\text { I was not entitled to buy the product that I wanted } \\
\text { (because of duty free regulations). }\end{array}$ & 8 & 8.4 \\
\hline Preferred to have something to eat / drink & 10 & 10.5 \\
\hline Other & 9 & 9.5 \\
\hline
\end{tabular}




\footnotetext{
${ }^{i}$ Aeronautical Revenues are defined as all revenues earned by the airport from aviation activity including landing charges, passenger load fees, airbridge fees, cargo throughput, rents for check-in desks and offices, aviation fuel throughput charges and the provision of security. In contrast, Commercial Revenues relate to all revenues earned by the airport authority from non-aviation sources, including concession fees from shopping, banking, catering and bars, car parking, advertising sign rentals.

${ }^{i i}$ Non commercial activities included phoning, using the toilet, fixing bags, asking directions etc.

iii The penetration rate is defined as the total number of passengers purchasing as a percentage of the total number travelling.

iv The variables chosen reflected the segments popularly used by the airport industry to categorise passengers. These were gender; country of residence; airline used; destination; purpose of travel (business, pleasure, visiting friends and relatives); method of travel (alone, group no children, group with children); duration of travel and age of respondent. In addition the research wished to explore whether an individuals behaviour was influenced by: the entry point used into the commercial area (two existed); being stopped, frisked and having their bags checked; the number of flights taken and the departure gate used (A,B or C).

v These were News, Spirits, Tobacco, Wine, Perfume/Cosmetics, Jewellery, Chocolate / Confectionary, Clothing, Music, Electrical, Luggage, Souvenirs, Meals, Other.
} 